\title{
Karakterisasi Morfologi Populasi Etlingera elatior (Jack) R.M.Sm. (Zingiberaceae) di Sumatera Barat
}

\section{Morphological Characterization of Population Etlingera elatior (Jack) R.M.Sm. (Zingiberaceae) in West Sumatra}

\author{
Zola Anjelia Putri ${ }^{1)}$, Nurainas ${ }^{2)}$ dan Syamsuardi2) \\ 1)Laboratorium Taksonomi Tumbuhan, Jurusan Biologi FMIPA Universitas Andalas, Sumatera Barat \\ ${ }^{2)}$ Herbarium Universitas Andalas (ANDA), Jurusan Biologi FMIPA Universitas Andalas \\ ${ }^{*}$ Korespondensi : nurainas@fmipa.unand.ac.id
}

\begin{abstract}
Research about morphological characterization of Etlingera elatior (Jack) R.M.Sm. (Zingiberaceae) was conducted from August to December 2016 in West Sumatra regions (Kepulauan Mentawai, Solok, and Padang Pariaman) and Padang city. Etlingera elatior has been used as traditional medicines for several diseases. Etlingera elatior was used for the treatment of various diseases. Effectivityof this plant depend on the preciseus in of the determinating variants type. The aim of this research was analyzed morphological variation among populations of Etlingera elatior. Survey and direct sampling method were used and continued by measurement of morphological characters of Etlingera elatior. Classification analyzed by cluster analysis with PAST program. Based on differentiation of the bract color of flowers, four variants of Etlingera elatior in West Sumatra were clarified those were 'red', 'pink', 'pale pink', and 'white' variant. The result of cluster analysis of 53 individuals Etlingera elatior indicated that many of 'white' and the 'red' variant were clustered in the same main cluster and individuals of 'pale pink' variant mostly clustered to 'red' variant and some of them were existed in the 'pink' variant.
\end{abstract}

Keyword : Etlingera elatior, morphological characters, population, variation, Zingiberaceae

\section{Pendahuluan}

Etlingera merupakan salah satu genus dalam tribe Alpineae. Genus ini tersebar dan merupakan tumbuhan asli di India, Bangladesh, Burma, China, Laos, Vietnam, Thailand, Malaysia, Singapura, Indonesia, Brunei, Papua New Guinea, dan Australia (Poulsen, 2006). Etlingera elatior merupakan salah satu jenis dari Etlingera. Jenis inimemiliki beberapa variasi pada bunganya yaitu E. elatior dengan bunga berwarna merah, E. elatior dengan bunga berwarna pink dan E. elatior dengan bunga berwarna putih (Larsen et al, 1999)

Berdasarkan hasil observasi di lapangan, E. elatior di Sumatera Barat memiliki beberapa variasi. Variasi ditemukan pada warna bunga. Ditemukan tiga variasi warna pada bunga yaitu warna merah, warna pink atau merah muda dan warna putih. Hasil temuan sebelumnya (RISTOJA, 2012) melaporkan bahwa varian tertentu dari tumbuhan ini telah digunakan secara spesifik untuk mengobati penyakit tertentu. E. elatior varian dengan warna merah digunakan untuk mengobati luka luar (Mentawai) sedangkan secara umum tumbuhan ini digunakan untuk mengobati penyakit maag (tanpa memperhatikan varian).

Pemanfaatan E. elatior sebagai obat tradisional sangat memerlukan autentifikasi dari jenis ini yaitu kejelasan tentang populasi atau varian dari $E$. elatior. Oleh karena itu karakterisasi ciri-ciri seperti ukuran, bentuk, warna dan struktur, perawakan sangat diperlukan. Karena dari karakterisasi morfologi akan didapatkan informasi mengenai kejelasan populasi atau varian mana yang digunakan sebagai obat tradisional karena setiap populasi atau varian mempunyai ciri spesifik yang membedakan antar setiap populasi atau variannya. Sehingga dilakukan penelitian ini untuk mengamati variasi morfologi beberapa varian E. elatior di Sumatera Barat dengan melakukan studi morfometrik untuk melihat 
variasi dan pengelompokan yang terbentuk. Penelitian ini akan mengelompokan populasi E. elatior dengan menggunakan karakter morfologi untuk memperjelas pengelompokan dari taksa tersebut.

\section{Metode Penelitian}

Penelitian ini dilaksanakan dari bulan Agustus sampai Desember 2016 di Kabupaten Padang Pariaman, Solok, Kepulauan Mentawai dan kota Padang. Spesimen penelitian di simpan di Herbarium ANDA Jurusan Biologi, Fakultas Matematika dan Ilmu Pengetahuan Alam, Universitas Andalas.

Metode yang digunakan pada penelitian ini adalah metode survei. Pengumpulan data dilapangan dilakukan dengan cara jelajah dan koleksi langsung. Dilakukan pengamatan karakter-karakter dan koleksi langsung terhadap semua populasi yang ditemukan, pencatatan data atau informasi yang penting di lapangan berupa karakter morfologi yang mungkin hilang setelah pengawetan. Kemudian dilakukan pengawetan lapangan terhadap sampel yang didapatkan. Selanjutnya dilakukan pengukuran karakter morfologi dan analisis data.

\section{Analisis Data}

Analisis data menggunakan metode Davis dan Heywood (1963) dengan tahapan analisis sebagai berikut : Penentuan STO (Satuan Taksonomi Operational). Seleksi karakter dengan melakukan pengukuran pada karakter yang dipilih untuk dianalisis secara morfometrik. Setelah didapatkan nilai dari masing-masing karakter selanjutnya data distandarisasi.

Analisis Kluster digunakan untuk mengetahui nilai statistik pengelompokan. Analisis pengelompokan (Cluster Analysis) diolah dengan menggunakan program komputer PAST (Paleontolgical Stastistics) versi 2.17c sehingga didapatkan dendrogram (Hammer, 2001).

\section{Hasil dan Pembahasan}

Berdasarkan penelitian yang telah dilakukan, E. elatior dikoleksi sebanyak 53 individu dari beberapa lokasi di Sumatera Barat yaitu
Kabupaten Kepulauan Mentawai (Siberut Utara dan Siberut Tengah), Solok (Simanau, Kec.Tigo Lurah dan Lubuk Selasih, Kec Gunung Talang), Padang Pariaman (Jorong Gamaran, Kec. Lubung Alung, Kab. Padang Pariaman), dan kota Padang (Bungus Kec. Teluk Kabung). Total karakter morfologi yang diamati adalah 85 karakter yang memiliki perbedaan dan nilai pengukuran yang bervariasi untuk mendukung pengelompokan E. elatior terdiri dari 51 karakter kuantitatif dan 34 karakter kualitatif.

Perbandingan karakter morfologi varian-varian E. elatior di Sumatera Barat

Hasil observasi terhadap 53 individu E. elatior di Sumatera Barat didapatkan empat varian E. elatior. Penentuan varian E. elatior berdasarkan perbedaan warna braktea. Warna braktea E. elatior dikelompokan menjadi empat yaitu warna merah, merah muda, pink pucat dan putih. Sehingga berdasarkan perbedaan warna braktea maka $E$. elatior dipisahkan menjadi empat varian yaitu, E. elatior 'merah', E. elatior 'merah muda', E. elatior 'pink pucat' dan E. elatior 'putih'(Gambar 1). Menurut Poulsen (2007), warna bunga pada pada E. elatior adalah warna merah muda dan merah muda pucat (Pale pink) dan kadang berwarna putih.

Varian-varian E. elatior dibedakan berdasarkan perbedaan warna braktea. Warna buah tidak dijadikan karakter untuk membedakan varian $E$. elatior karena karakter warna buah tidak memiliki variasi yang tinggi jika dibandingkan dengan warna braktea pada bunga majemuk E. elatior. Warna buah yang ditemukan adalah dua variasi warna yaitu merah keunguan dan kuning kecoklatan. Sampel buah E. elatior yang ditemukan sebagian besar berwarna kuning kecoklatan kecuali pada E. elatior 'merah muda' yang didapatkan di Solok dan Padang Pariaman.

Perbedaan karakter morfologi varianvarian E. elatior terlihat jelas pada warna beberapa karakter (tabel 1. ). Perbedaan warna terdapat pada karakter warna lamina, braktea steril, braktea fertil, brakteola, calyx, corolla tube, corolla lobe, labellum, stigma, dan buah sedangkan warna filament dan antera sama untuk empat varian E. elatior. Empat varian 
E. elatior yang ditemukan di Sumatera Barat, E. elatior 'putih' merupakan varian yang memiliki karakter-karakter yang berbeda signifikan dibandingkan dengan karakter varian lainnya.

Tabel 1.Perbandingan karakter morfologi empat varian E. elatior di Sumatera Barat

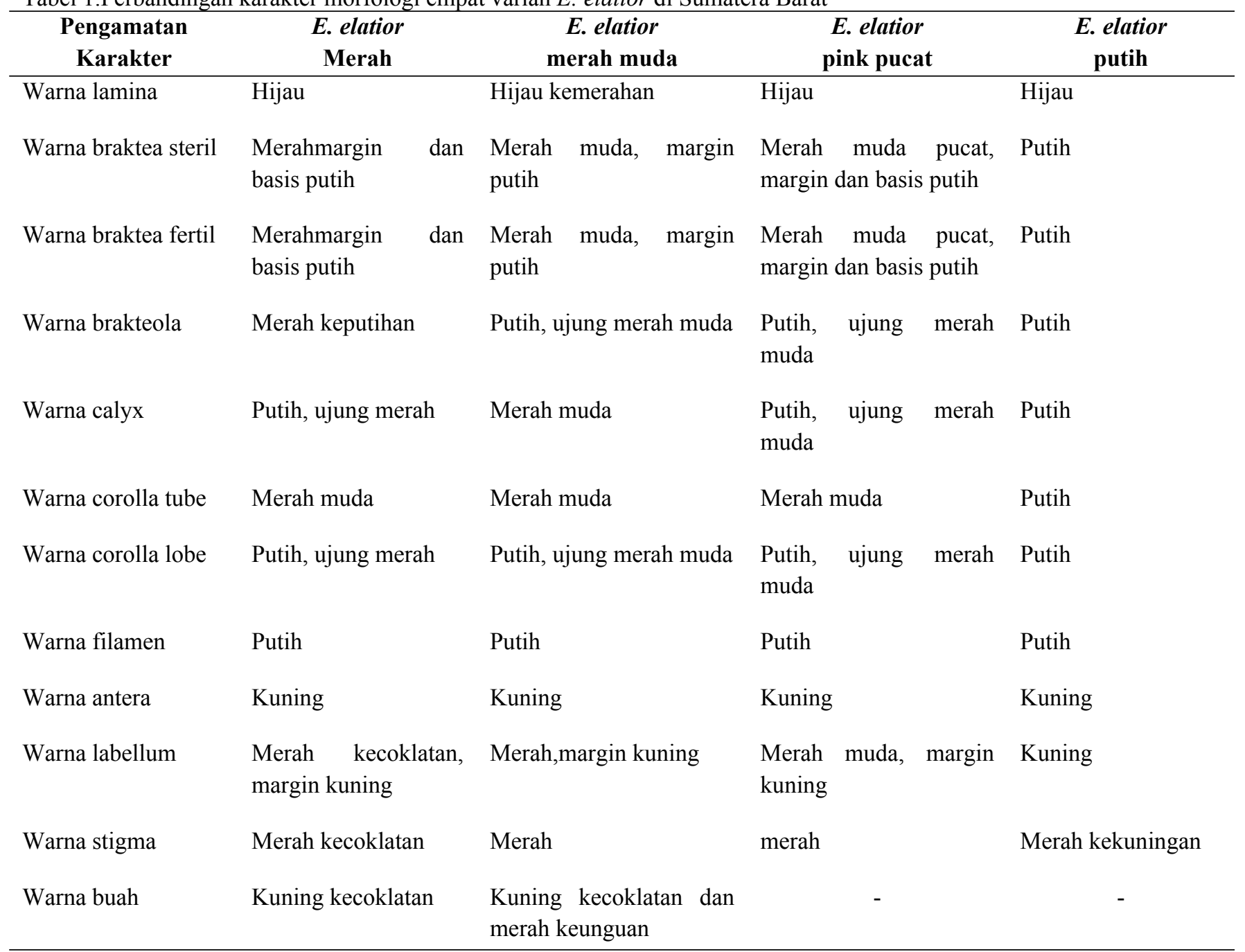

Brakteola varian 'merah' (Gambar 4)

E. elatior memiliki dua macam braktea yaitu braktea fertil (Gambar 2) dan braktea steril (Gambar 3). Bentuk braktea steril oblongus dan bentuk braktea fertil sphatulated. Braktea fertil varian 'merah' memiliki panjang 4-9 $\mathrm{cm}$, lebar $2-5 \mathrm{~cm}$. Varian 'merah muda', panjang 3,5-5 cm, lebar 0,5-1,5 cm. Varian 'pink pucat', panjang $6 \mathrm{~cm}$ dan lebar $1,5 \mathrm{~cm}$ dan varian 'putih', panjang 1,4 cm dan lebar $2 \mathrm{~cm}$. Poulsen (2012) mengatakan braktea steril E. elatior berwarna merah muda sampai merah muda pucat dan kadang-kadang berwarna merah. Braktea fertil E. elatior merah muda dan merah muda lembut. bentuk umum retusus, ujung emarginatus.Varian 'merah' dengan panjang 1,4-3,6 cm dan lebar 0,3-0,8 cm. Varian 'merah muda'dengan panjang 1,8-3,3 cm dan lebar 0,3-1,8 cm. Varian 'pink pucat' dengan panjang 2,1 cm dan lebar $6,5 \mathrm{~cm}$ dan varian 'putih' dengan panjang2-2,5 $\mathrm{cm}$ dan lebar 0,5-1,2 cm, Poulsen (2007) menyebutkan warna brakteola E. elatior merah muda pucat (pale pink) sampai merah di bagian ujung.

Kelopak pada varian 'merah' (Gambar 5) retusus, permukaan licin, ujung emarginatus, panjang kelopak 1,1-4 cm. Varian 'merah muda' 
(Gambar 5) retusus, permukaan licin, ujung emarginatus, panjang kelopak 2,8 $\mathrm{cm}$. Varian 'pink pucat' (Gambar 5) retusus, permukaan licin, ujung emarginatus, panjang kelopak $2,5 \mathrm{~cm}$ dan varian 'putih' (gambar 5) retusus, permukaan licin, ujung emarginatus, panjang kelopak 2,3-3,1 cm. Menurut Khaw (2001), panjang dan lebar kelopak E. elatior 2,5-3 x 1,5 cm, permukaan licin, warna putih dan merah muda pada bagian ujung.

Corolla tube varian 'merah', panjang 1,3-4 cm. Varian 'merah muda' panjang 1,2-3,3 $\mathrm{cm}$. Varian 'pink pucat', panjang $2 \mathrm{~cm}$ dan varian 'putih', panjang $1,4-3,3 \mathrm{~cm}$. Bentuk corolla lobe E. elatior 'merah' sphatulated, warna putih dan merah pada ujung. Varian 'merah muda' sphatulated, warna putih dan bagian ujung merah muda. Varian 'pink pucat' sphatulated, warna putih sampai merah muda dan varian 'putih' sphatulated, warna putih.

Filamen varian 'merah' bentuk silindris, antera elipticus, panjang 0,5-1,2 dan lebar 0,2-0,6 cm. Filamen varian 'merah muda' panjang 0,1-1,3 dan lebar 0,1-0,3 cm, warna putih. Antera elipticus, panjang 0,5-1,3 $\mathrm{cm}$ dan lebar 0,1-0,4 cm. Varian 'pink pucat' filamen silindris, panjang $0,4 \mathrm{~cm}$ dan lebar $0,2 \mathrm{~cm}$, warna putih. Antera elipticus, panjang $0,6 \mathrm{~cm}$ dan lebar0,3 cm. Varian 'putih' filamen silindris, panjang 0,3-0,9 cmdan lebar 0,1-0.2 cm, putih. Antera elipticus, panjang $0,7-1,1 \mathrm{~cm}$ dan lebar $0,1-0,3 \mathrm{~cm}$.

Labellum (Gambar 7.) varian 'merah' ovatus, warna merah kecoklatan, pinggir berwarna kuning. Labellum varian 'merah muda' ovatus, warna merah dan margin kuning. Labellum varian 'pink pucat' ovatus, warna merah muda dan margin kuning. Labellum varian 'putih' ovatus, warna kuning dan dasar warna putih. Varian 'putih' memiliki labellum yang jauh berbeda dibandingkan ketiga varian lainnya. Menurut Poulsen (2007), labellum E. elatior biasanya berwarna merah dan pinggir warna kuning.

Stilus varian 'merah' silindris, panjang 2,9-4,8 cm, warna putih. Stilus varian 'merah muda' silindris, panjang $0,4-4 \mathrm{~cm}$, warna putih.
Stilus varian 'pink pucat' silindris, panjang $2,9 \mathrm{~cm}$, warna putih. Stilus varian 'putih' silindris, panjang $0,3-0,5 \mathrm{~cm}$, dan warna putih. Stigma varian merah', panjang 0,1-0,4 cm, warna merah kecoklatan. Stigma varian 'merah muda' panjang 0,1-0,3 cm, warna merah sampai merah kecoklatan. Stigma varian 'pink pucat', panjang $0,3 \mathrm{~cm}$, warna merah. Stigma varian 'putih' panjang $0,2-0,3 \mathrm{~cm}$, warna merah kekuningan.

Ovari E. elatior 'merah' silindris, permukaan berambut, panjang 0,3-1,4 cm, diameter $0,2-0,5 \mathrm{~cm}$ dan warna putih kemerahan. Ovari E. elatior 'merah muda' silindris, permukaan berambut, panjang 0,2-0,7 cm, diameter $0,1-0,2 \mathrm{~cm}$ dan warna putih. Ovari E. elatior 'pink pucat' silindris, panjang $0,3 \mathrm{~cm}$ dan diameter $0,2 \mathrm{~cm}$, permukaan berambut, warna putih kemerahan. Ovari E. elatior 'putih' silindris, panjang $0,3-0,5 \mathrm{~cm}$ dan diameter $0,2-$ $0,4 \mathrm{~cm}$, permukaan berambut, warna putih.

Buah E. elatior merupakan buah majemuk. Satu tangkai buah terdiri dari 15-95 buah, bentuk buah ovoid. Warna buah E. elatior ada dua variasi yaitu, warna merah keunguan dan kuning kecoklatan. Menurut Yandi (2009), buah masak E. elatior berwarna merah muda dan biji warna hitam. Menurut Poulsen (2012) buah E. elatior merupakan buah majemuk dan warna buah merah, merah muda dan hijau kekuningan.

Buah varian 'merah', warna kuning kecoklatan, total buah pada buah majemuk 1595 buah, diameter spike $6-10 \mathrm{~cm}$. Biji hitam dengan panjang $0,3-0,7 \mathrm{~cm}$ dan diameter $0,2-0,3$ $\mathrm{cm}$. Varian'merah muda', buah warna kuning kecoklatan dan merah keunguan. Total buah pada buah majemuk adalah 15-70 buah, diameter spike $5-11 \mathrm{~cm}$. Biji berwarna hitam dengan panjang 0,1-0,6 $\mathrm{cm}$ dan diameter 0,1-0,5 cm. Khaw (2001) mengatakan buah majemuk E. elatior berbentuk elongate dengan jumlah buah 15-25 buah. Buah berbentuk obovoid. 


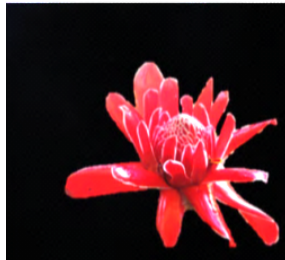

a

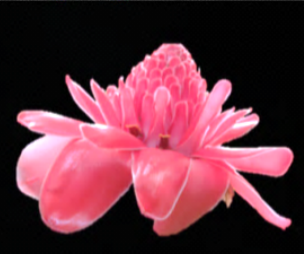

b

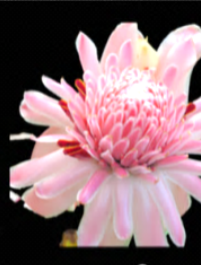

C

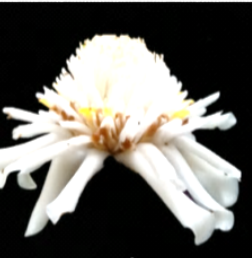

d

Gambar 1. Bunga majemuk E. elatior,a) varian 'merah', b). varian'merah muda'

c) varian 'Pink pucat', dan d) varian'putih'

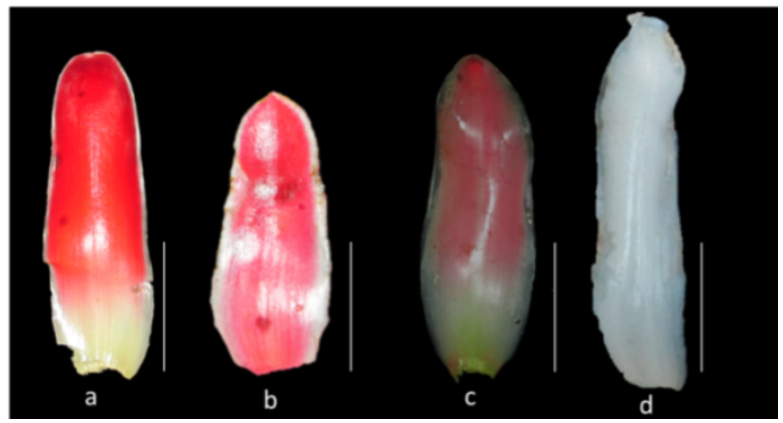

Gambar 2.Bentuk braktea steril E. elatior a.)varian 'merah'; b) varian 'merah muda', c) varian'pink pucat', d) varian 'putih'. Skala $2 \mathrm{~cm}$.

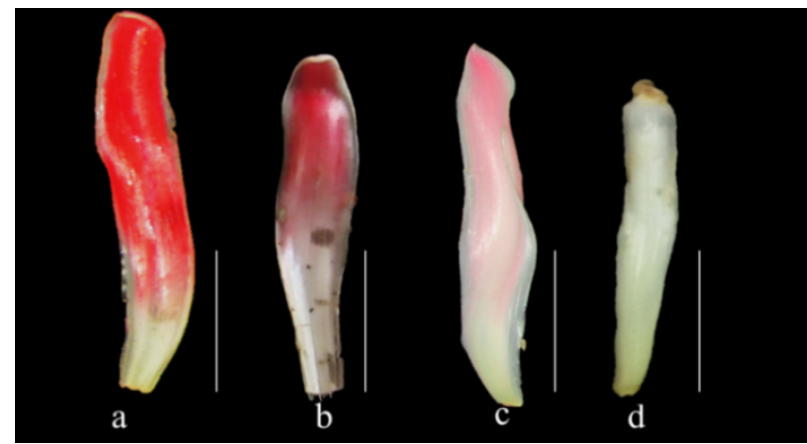

Gambar 3. Bentuk braktea fertil E. elatior a) varian'merah', b) varian 'merah muda';c) varian 'pink pucat' d) varian 'putih'. Skala: $2 \mathrm{~cm}$.

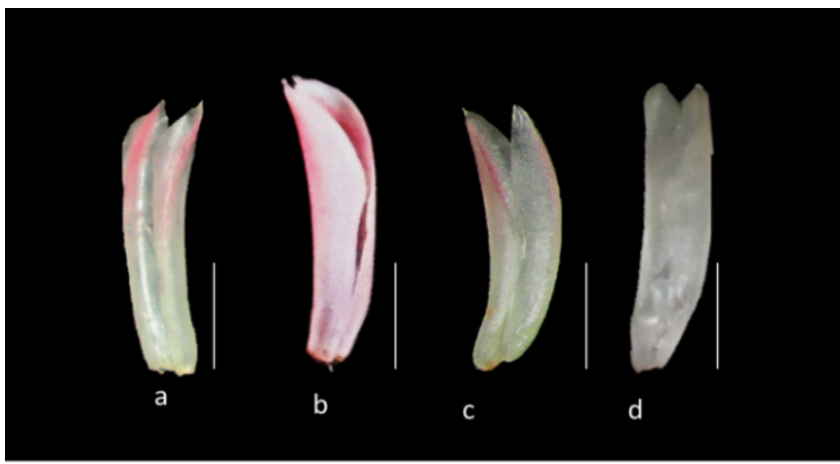

Gambar 4. Bentuk brakteola E. elatior d. varian 'putih'. Skala: $1 \mathrm{~cm}$

a) varian'merah'; b) varian'merah muda'; c) varian'pink pucat'; 
Jurnal Biologi Universitas Andalas (J. Bio. UA.)

5(1) - November 2017: 25-33 (ISSN : 2303-2162)

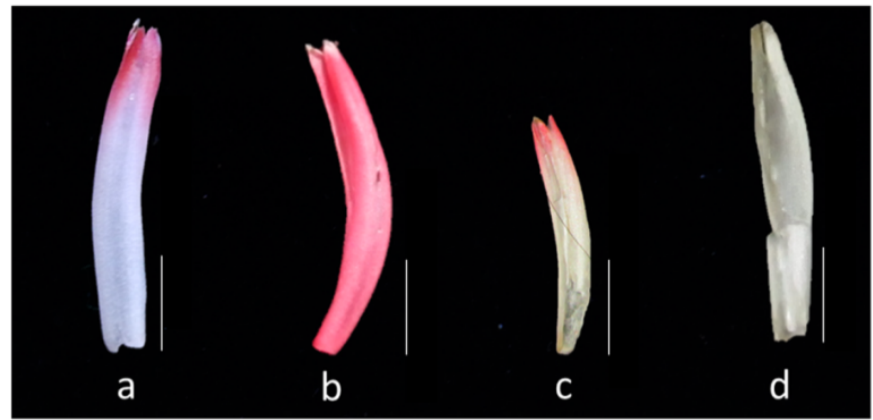

Gambar 5. Bentuk calyx E. elatior a) varian 'merah'; b) varian 'merah muda'; c) varian 'pink pucat';d) varian 'putih'. Skala $1 \mathrm{~cm}$

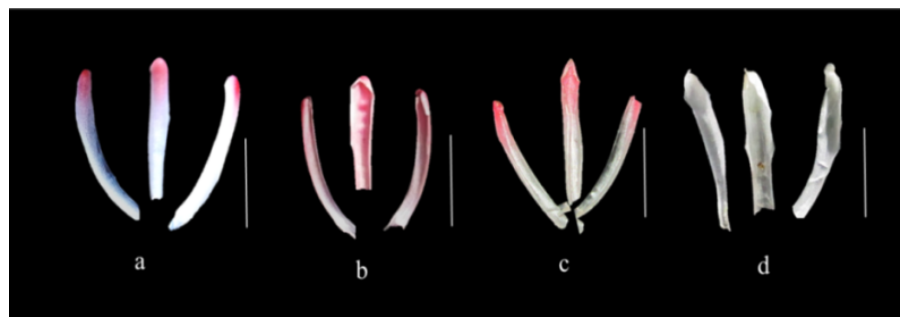

Gambar 6. Bentuk corolla lobe E. elatior a) varian 'merah'; b) varian 'merah muda'; c) varian 'pink pucat';d) varian 'putih'. Skala $2 \mathrm{~cm}$

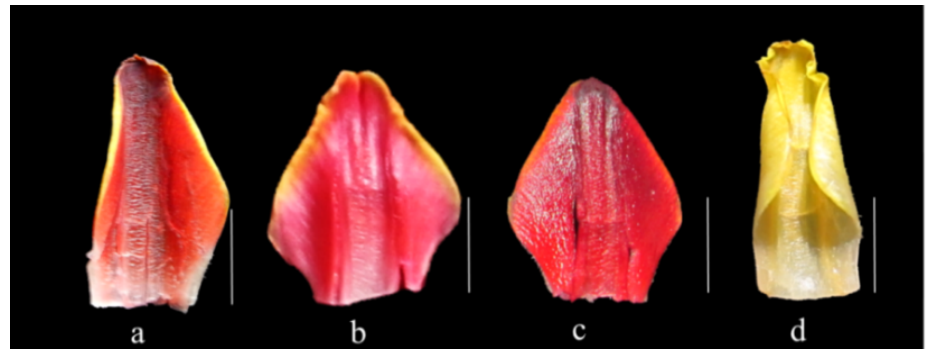

Gambar 7. Bentuk labellum a) varian 'merah'; b) varian'merah muda'; c) varian 'pink pucat';d) varian 'putih'. Skala: $1 \mathrm{~cm}$

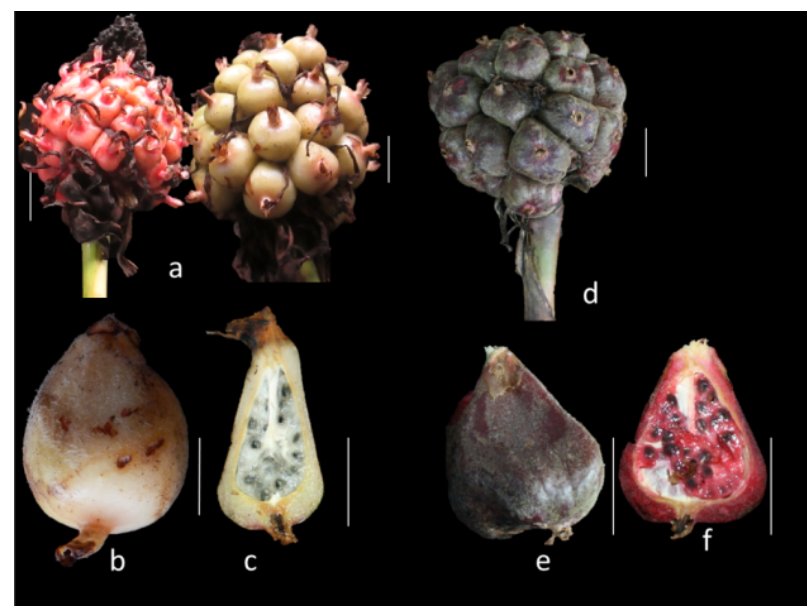

Gambar 8. Bentuk buah E. elatior a. buah majemuk varian 'merah', varian 'merah muda',b. buah varian 'merah', varian 'merah muda'; c. buah varian 'merah muda' (Solok dan Lubuk Alung) d. buah varian 'merah muda' (Solok dan Lubuk Alung). Skala: $2 \mathrm{~cm}$. 


\section{Analis Kluster}

Analisis pengelompokan (clustering) yang dilakukan terhadap 53 individu (Satuan Taksonomi Operasional/ STO) (Gambar 9), E. elatior mengelompok menjadi dua kelompok besar. Kelompok 1 terdiri dari varian varian 'merah' dan varian 'putih'. Kelompok 2 terdiri dari varian 'merah muda' tapi terdapat varian lain yang ikut mengelompok pada kelompok 1 yaitu varian 'merah muda' dan varian 'pink pucat'. Sedangkan pada kelompok dua mengelompok varian 'merah' dan varian 'pink pucat'. Secara umum, dendogram memperlihatkan bahwa varian 'merah' memiliki pengelompokan yang lebih dekat dengan varian 'putih', sedangkan varian 'pink pucat' (Simanau) memiliki pengelompokan yang lebih dekat dengan varian 'merah' dan varian 'pink pucat' (Mentawai) memiliki pengelompokan yang lebih dekat dengan varian 'merah muda'.

Berdasarkan dendogram (Gambar 9) menunjukan sebagian kelompok individu E. elatior mengelompokan berdasarkan asal dari populasi, sebagian lainnya mengelompok berdasarkan varian E. elatior dan sebagian lainnya mengelompok secara acak bergabung dengan populasi lainnya berdasarkan varian dan juga berdasarkan asal wilayah. Hal tersebut dapat terjadi karena terjadinya diferensiasi morfologi yang berbeda yang diakibatkan perbedaan habitat varian $E$. elatior, sehingga walaupun dikelompokan dalam kelompok yang sama berdasarkan karakter morfologi namun dalam pengelompokan numerik varian ini berbeda karena kelompok ini memiliki tingkat similaritas yang rendah. Seperti yang dikatakan Hayati (2014), pemisahan dapat terjadi akibat adanya diferensiasi morfologi yang lebih tinggi pada individu tersebut dari individu lainnya dalam satu kelompok. Menurut Tamaru (1981) dalam Hayati (2014) diferensiasi morfologi dalam sebuah populasi dapat terjadi karena terjadinya perbedaan respon individu-individu satu spesies terhadap lingkungan tempat berkembangnya.

Pengelompokan E. elatior yang terlihat pada dendogram (Gambar 9) dapat terjadi karena nilai jarak dan kesamaan dari karakter-karakter yang diamati dan diukur. Dendogram memperlihatkan semua tipe E. elatior mengelompok berdasarkan varian, tapi masih ada beberapa varian yang tidak mengelompok sesuai dengan varian. Hal tersebut menunjukan bahwa terdapat banyak kesamaan karakter di antara tipe-tipe E. elatior yang diamati sehingga E. elatior terkelompok berdasarkan variannya. 


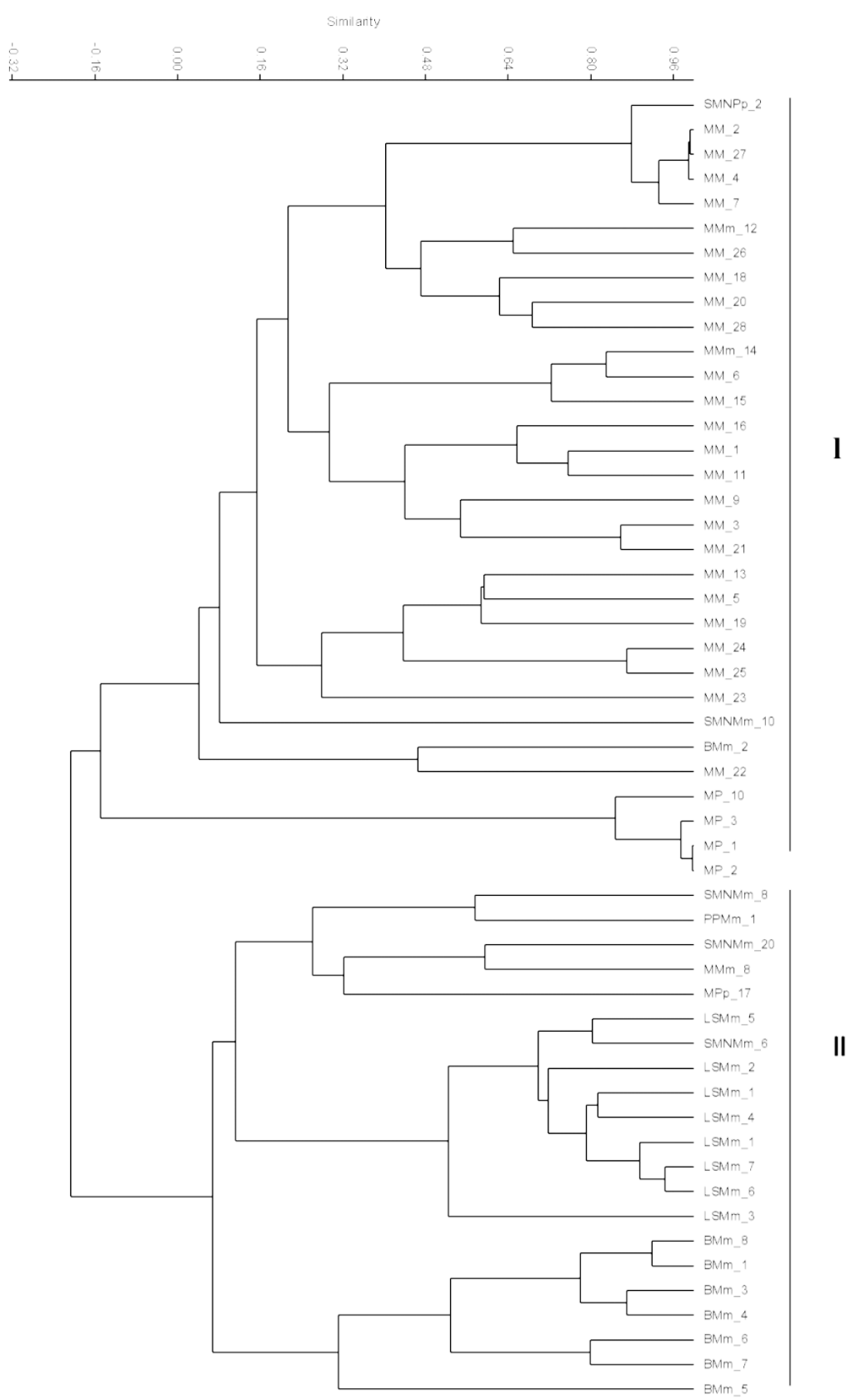

Gambar 9. Dendogram dari 53 STO E. elatior di Sumatera Barat berdasarkan karakter morfologi. Ket: SMNPp (Simanau pink pucat), MM (Mentawai merah), MMm (mentawai Merah muda), SMNMm (Simanau Merah Muda), MPp (Mentawai pink pucat), MP (mentawai Putih), LSMm (Lubuk Selasih Merah muda), PPMm (Padang pariaman Merah Muda) dan BMm (Bungus Merah Muda)

\section{Kesimpulan}

Berdasarkan hasil penelitian yang telah dilaksanakan, dapat disimpulkan E. elatior di Sumatera Barat di bedakan menjadi empat varian berdasarkan warna braktea yaitu varian 'merah', varian 'merah muda', varian 'pink pucat', dan varian 'putih'. Varian 'putih' secara karakter morfologi mengelompok dengan varian 'merah', dan varian 'pink pucat' sebagian mengelompok dengan varian 
'merah' dan sebagian lagi mengelompok dengan varian 'merah muda'.

\section{Ucapan Terima Kasih}

Ucapan terima kasih di tujukan kepada Kementrian Kesehatan Badan Penelitian Dan Pengembangan Tanaman Obat dan Obat Tradisional yang telah membantu sebahagian dana untuk penelitian dalam kegiatan RISTOJA (Riset Tumbuhan Obat dan Jamu) serta kepada Dr. Tesri Maideliza, Ibu Solfiyeni MP, dan Ibu Mildawati M.Si yang telah memberikan masukan, kritik, dan saran dalam melakukan penelitian hingga penyelesaian penelitian ini.

\section{Daftar Pustaka}

Hayati, Winda., A. Arbain., dan Syamsuardi. 2014. Studi Mikromorfologi Kapsul dan Spora serta Implikasinya Terhadap Pengelompokan Lumut Pogonatum P. Beauv.(Polytrlchaceae). Jurnal Biologi Universitas Andalas (J. Bio. UA.). 3(1)-Maret 2014: 80-86

Davis, PH. and Heywood VH. 1963. Principles of Angiosperm Taxonomy. Robert E. Krieger Publishing Company. New York.
Hammer, O. 2001. Reference Manual PAST (Paleontological Statistics) version 2.17c. Universitas of Oslo. Oslo.

Khaw, S. H. 2001. The Genus Etlingera (Zingiberaceae) in Peninsular Malaysia Including a New Spesies. Garden's Bulletin Singapore53 : 191-239.

Laporan RISTOJA-2012 Propinsi Sumatera Barat. 2012. Riset khusus eksplorasi pengetahuan local etnomedisine dan tumbuhan di Indonesia berbasisi komunitas. Lembaga Peneliti an dan Pengabdian Kepada Masyarakat Universitas Andalas berkerjasama dengan Badan Litbang Kesehatan

Larsen, K., H. Ibrahim., S. H. Khaw., and L. G. Saw. 1999. Gingers of Peninsular Malaysia and Singapore. Natural History Publications. Malaysia.

Poulsen, A.D., 2006. Gingers of Sarawak. Natural History Publications. Malaysia.

Poulsen, A. D., 2007. Etlingera Giseke of Java. Garden's Bulletin Singapore 59 (1 \& 2): 145-172.

Yandi, S. 2009. Jenis-Jenis Zingiberaceae yang Ditemukan di Kawasan Hutan Lindung Gunung Bungsu Kab.50 Kota.UNAND. Padang. 